\title{
EFEKTIFITAS MASASE TERAPI CEDERA OLAHRAGA TERHADAP NYERI TUMIT DAN NYERI OTOT TIBIALIS PADA ATLET FUTSAL SMA NEGERI 1 CIAMIS
}

\author{
Aap Subhan Sa'roni ${ }^{1}$ dan Ali Satia Graha ${ }^{1}$ \\ ${ }^{1}$ Fakultas Ilmu Keolahragaan, Universitas Negeri Yogyakarta, Colombo No. 1, Karangmalang Depok, Sleman, \\ Yogyakarta, Indonesia \\ aap.subhan2015@student.uny.ac.id,ali_satiagraha@uny.ac.id
}

\begin{abstract}
Abstrak
Olahraga futsal merupakan olahraga yang berintensitas tinggi yang ditandai dengan adanya aktivitas berlari secara berulang- ulang dengan waktu yang relatif lama sehingga beresiko cedera pada kaki. Gangguan nyeri tumit dan nyeri otot tibialis banyak terjadi pada pemain futsal. Tujuan penelitian ini adalah untuk mengetahui efektifitas masase terapi cedera olahraga terhadap nyeri tumit dan nyeri otot tibialis pada atlet futsal SMA Negeri 1 Ciamis. Penelitian ini merupakan penelitian Pre-Experimental dengan desain one group pretest-posttest design. Populasi dalam penelitian ini adalah pemain ektrakurikuler futsal SMAN Negeri 1 Ciamis. Teknik pengambilan sampel yaitu dengan menggunakan teknik Purposive Sampling berdasarkan kriteria inklusi dan ekslusi sehingga didapatkan sampel sebanyak 30 orang diantaranya 15 orang mengalami keluhan nyeri tumit dan 15 orang mengalami keluhan nyeri otot tibialis. Data yang dikumpulkan adalah derajat nyeri tumit da nyeri otot tibialis sebelum dan sesudah perlakuan. Teknik analisi data menggunakan analisis deskriptif dan uji prasyarat dengan menggunakan uji normalitas menggunakan metode Kolmogrof-Smirnof dan Shafiro-walk, uji homogenitas menggunakan uji Levane Test, dan di analisis dengan uji hipotesis menggunakan Paired Sample t-Test untuk menjawab hipotesis yang diajukan. Hasil penelitian menunjukan bahwa masase terapi cedera olahraga efektif terhadap penurunan rasa nyeri tumit dan nyeri otot tibialis pada atlet futsal SMA Negeri 1 Ciamis. Penelitian ini menjukan adanya perbedaan rata-rata nilai nyeri antara nyeri pada sebelum perlakuan (pretest) dan sesudah perlakuan (posttest).
\end{abstract}

Kata kunci: Masase terapi cedera olahraga, nyeri tumit, nyeri otot tibialis.

\section{THE EFFECTIVITY OF THERAPY MASSAGE FOR SPORT INJURY TOWARD HEEL AND MUSCLE TIBIALIS PAIN IN ONE SENIOR HIGH SCHOOL (CIAMIS) FUTSAL ATHLETES}

\begin{abstract}
Futsal is a high-intensity sport that is characterized by the activity of running repeatedly with a relatively long period of time so tend to induce risk of injury inside feet. Heel pain and tibial muscle pain are commonly injuries of futsal players. The purpose of this study was to determine the effectiveness of massage therapy for sports injuries to heel pain and tibial muscle pain in futsal athletes of SMA Negeri 1 Ciamis. This research is a Pre-Experimental study with one group pretest-posttest design. The population in this study were futsal extracurricular players of SMAN Negeri 1 Ciamis. The sampling technique using Purposive Sampling technique based on inclusion and exclusion criteria to obtain a sample of 30 people including 15 people experiencing complaints of heel pain and 15 people experiencing complaints of tibial muscle pain. Data collected was the degree of heel pain and tibial muscle pain before and after treatment. Data analysis techniques used descriptive analysis and prerequisite tests using the normality test using the Kolmogrof-Smirnof and Shafiro-walk methods, homogeneity tests using the Levane Test, and analyzed with the hypothesis test using Paired Sample tTest to answer the proposed hypothesis. The results showed that massage therapy for sports injuries was effective in decreasing heel pain and tibial muscle pain in futsal athletes of SMA Negeri 1 Ciamis.
\end{abstract}


This research shows that there is a difference in the average value of pain between pain before and after the treatment (posttest).

Keywords: Sport therapy massage, heel pain, muscle tibialis pain

\section{PENDAHULUAN}

Perkembangan olahraga di era milineal saat ini mengalami kemajuan yang pesat, baik dari manajemen bisnis, IPTEK, dan program latihan untuk meningkatkan prestasi, kebugaran maupun kesehatan. Khususunya pada program latihan yang diberikan oleh para pelatih atau instruktur secara berlebihan atau tidak sesuai dengan porsinya akan menimbulkan cedera. Salah satu faktor penyebab cedera olahraga adalah penggunaaan yang berlebihan dan berulang- ulang dalam waktu relatif lama ketika latihan (overuse syindrome) dapat menyebabkan cedera (Setiawan, 2011: 94).

Cedera merupakan salah satu hambatan bagi olahragawan atau atlet dalam meraih prestasi olahraga. Faktor terjadinya cedera yang dialami atlet diantaranya karena riwayat cedera sebelumnya, kelelahan otot, dan gerakan fungsional kaki yang tidak baik dikarenakan kurang nya pemanasan (Warming up) dan peregangan (Streching) saat melakukan olahraga (McCall, 2015: 1). Cedera pada pemain futsal bisa terjadi pada saat kontak fisik dengan lawan, terlalu berat latihan yang diberikan (overtraining), kesalahan teknik menendang bola, terjatuh pada saat kontak fisik.

Olahraga futsal merupakan pengganti olahraga sepakbola yang sering terjadi adanya body contac dan rawan akan cedera. Cedera yang sering dialami oleh pemain futsal sebagian besar terjadi pada ektremitas bawah yang meliputi lutut dan ankle. Cedera yang dialami oleh pemain futsal menunjukan paling tinggi pada bagian ektremitas bawah $47.18 \%$, cedera pada bagian ektremitas atas $19.01 \%$, cedera pada bagian togok $18.31 \%$, dan pada bagian kepala sebanyak 15.49\% (Wahyu 2013: 78). Sebuah Hasil riset Injury risk of playing football in Futsal World Cups terdiagnosis cedera yang sering pada bagian kaki bawah yaitu cedera pada ankle sprain 9.7\%, dan groin strain $7.9 \%$.

Kaki merupakan bagian tubuh mulai dari pergelangan kaki sampai jari-jari kaki yang dimana dilengkapi dengan jaringan lunak seperti tendon yang merupakan bantalan untuk menahan berat badan tubuh yang menekan pada daerah tersebut. Fungsi utama kaki yaitu untuk menahan beban sehingga telapak kaki, jari-jari kaki, serta tumit sering mengalami gangguan. Penyebab nyeri di tumit pada pemain futsal diakibatkan karena pemakaian sepatu yang tidak sesuai dan sering berlari secara berlebihan (Goff, 2011: 677). Nyeri tumit atau calcaneal apophysitis disebabkan oleh aktivitas fisik yang melibatkan tumbukan terus menerus pada kaki. Rasa nyeri yang hebat dapat menyebabkan penderita menjadi pincang, tampak membengkak dan sakit jika disentuh (Fondy, 2016: 35).

Pengunaan yang berlebihan pada otot akibat dari latihan yang kompulsif dapat menyebabkan cedera (Anggoro, 2014: 2). Cedera yang sering dialami oleh atlet setelah latihan yaitu berupa kelelahan, kram otot, pegal otot dan ketegangan otot yang menyebabkan nyeri. Ketegangan otot dapat menyebabkan rasa sakit yang dapat membatasi pergerakan kelompok otot yang akhirnya jika dibiarkan akan menimbulkan cedera yang semakin parah seperti strain. Pembebanan yang terlalu banyak pada kaki akibat dari aktivitas terlalu sering berlari secara berulang-ulang di permukaan lapangan yang keras dapat mengakibatkan stres fraktur dan nyeri pada otot tibialis (Amin \& Moroz, 2017: 281).

Penanganan cedera banyak macam cara yaitu dengan pengobatan medis maupun non medis, pengobatan medis meliputi terapi rehabilitasi olahraga dengan menggunakan penanganan pengobatan alternatif dan olahraga terapi sebagai pilihan untuk penyembuhan pasca cedera yang dialami atlet tersebut yaitu terapi herbal, terapi masase, thermotherphy, 
coldtherphy, hydrotheraphy, manual theraphy, terapi yoga, exercise therapy, dan lain lain (Graha, 2009: 2).

Terapi masase merupakan salah satu cara untuk atlet melakukan recovery setelah latihan atau pertandingan. Berbagai macam terapi masase yang ditawarkan diantaranya shiatsu, tsubo, akupuntur, sport masase, deep tissue masase, frirage, dan masih banyak yang lainnya. Masingmasing dari teknik masase di atas mempunyai teknik manipulasi yang berbeda-beda khususnya pada masase frirage. Manipuasi masase frirage ada 4 cara yaitu gabungan teknik efflurage dan friction dilakukan secara bersamaan menggunakan ibu jari untuk memijat, traction (tarikan), dan reposition (reposisi) yang bertujuan untuk mengurangi ketegangan otot dan pemulihan cedera (Graha, 2012: 80).

Cedera pada pergelangan kaki (ankle) dapat menyebabkan rasa sakit ketika berjalan bahakan sampai tidak bisa berjalan. Cedera pada pergelangan kaki apabila dialami oleh seorang atlet maka atlet tersebut tidak akan bisa berlatih dan membutuhkan proses penyembuhan yang cukup lama untuk kembali berlatih. Penyebab utama cedera pergelangan kaki (ankle) adalah adanya penekanan yang kuat dan gerakan membelok atau memutar secara tiba-tiba sehingga ligament pada sendi robek (Fondy, 2016: 42). Cedera ankle atau ankle terkilir melibatkan satu atau beberapa ligament yang over-stretch atau ligament yang sobek. Berdasarkan berat ringannya cedera ankle dibagi dalam tiga tingkatan dari cedera ankle, sebagai berikut (Harun dan Fatimah, 2013: 36): 1) Sprain tingkat I. Cedera ini terdapat sedikit hematoma dalam ligamentum dan hanya beberapa serabut yang putus tetapi terasa sakit dan menimbulkan bengkak Arofah, (2009: 5). Cedera tingkat I ini membutuhkan waktu sekitar 5-7 hari untuk memulai taraf penyembuhan pertama dan total secara sembuh adalah sekitar 6 minggu; 2) Sprain tingkat II. Sprain tingkat II adalah tingkatan kerusakan jaringan lebih nyata. Ligament yang cedera mengalami over stretch yang menyebabkan bengkak dan rasa sakit tetapi ankle masih bisa berfungsi dengan baik dan masih bisa digunakan. Sprain tingak II memerlukan waktu 10 minggu untuk sembuh secara total (Harun dan Fatimah, 2013: 36); 3) Sprain tingkat III. Sprain tingkat III adalah cedera yang serius, yang ditandai adanya kerusakan jaringan pada tubuh berupa robekan pada ligament secara total disertai juga dengan fraktur yang menyebabkan terganggunya fungsi sendi (Wolfe, 2001: 1). Sprain tingkat III memerlukan waktu 12-16 minggu untuk sembuh secara total.

Masase dalam istilah ini berasal dari bahasa Arab "mass ' $h$ " yang artinya tekan dengan lembut (Furlan, 2004: 337). Masase pertama kali lahir di China sekitar 5000 tahun yang lalu. Perkembangan masase yang pesat terjadi ke Negara-negara Eropa dan Amerika. Masase telah diterima di bagian Amerika Utara sebagai pengobatan alternatif untuk kesehatan dan rehabilitasi. Masase mulai masuk ke Indonesia mengikuti perkembangan zaman kerajaan Hindu dan Budha ditandai dengan peninggalan candi dengan berbagai relief.

Di Indonesia saat ini mulai berkembang berbagai jenis masase antara lain: thai masase, masase Swedia, segment masase, accuprssure, tsubo, shiatsu, refleksi, dan lain-lain (Graha dan Priyonoadi, 2012: 8). Masase sendiri memiliki banyak manfaat untuk kebugaran, meliputi pemulihan, rileksasi, pencegahan, dan penanganan cedera. Berbagai macam terapi masase untuk perawatan dan penanganan cedera pada saat ini banyak digunakan antara lain: 1) Shiatshu, 2) Akupuntur, 3) Qi-gong, 4) Frirage, dan lain-lain.

Berdasarkan berbagai macam terapi masase di atas dapat dijabarkan sebagai berikut: a) Shiatshu adalah terapi pijat tradisional kuno dari China yang menggunakan tekanan jari seperti akupuntur untuk menyeimbangkan ke tidak seimbangan chi atau energi kehidupan seperti mental, fisik dan emosional yang menyebabkan sakit dan gangguan pada tubuh (Zen, 2017: 1); b) Akupuntur adalah salah satu pengobatan tradisional dari China dengan menggunakan jarum pada titik-titik tertentu di tubuh seseorang yang bertujuan untuk menstimulasi tubuh untuk memberikan energi yang bermanfaat untuk berbagai macam penyakit; c) Qi-gong adalah 
masase yang berasal dari China yang bermanfaat bagi tubuh untuk mengembalikan aliran energi disepanjang meridian-meridian dalam tubuh. Qi-gong meliputi seni gerakan yang lembut tanpa menggunakan kekuatan otot (Akoso et. al, 2005: 39); d) Frirage adalah terapi masase untuk kesehatan maupun penyembuhan pada cedera maupun penyembuhan pada bagian tubuh lainnya

Membahas lebih lanjut masase frirage, masase frirage menggunakan metode metode masase yang berasal dari ratusan atau ribuan macam metode masase lama maupun baru dari para ahli masase di dunia. Masase frirage berasal dari Indonesia yang diambil dari kata, masase yang artinya pijatan dan frirage yaitu gabungan antara friction (gerusan) dan efflurage (gosokan) yang dilakukan secara bersamaan dalam melakukan pijatan dengan menggunakan ibu jari (Graha \& Priyonoadi, 2012: 22).

Metode masase frirage bertujuan merawat cedera ringan seperti terkilir pada persendian dan kontraksi otot, perawatan tubuh, dan perawatan bayi. Manipulasi dalam masase frirage yaitu dengan 4 cara yaitu manipulasi friction, efflurage, traction (tarikan) dan reposition (reposisi) (Graha \& Priyonoadi, 2012: 80). Berikut penjelasan manipulasi masase frirage; 1) Manipulasi friction adalah manipulasi dengan cara menggerus dengan tujuan untuk menghancurkan myoglosis yaitu timbunan dari sisa-sisa pembakaran yang terdapat pada otot yang menyebabkan pengerasan serabut otot yang mengakibatkan timbulnya rasa nyeri (Yulianti, 2015: 22); 2) Manipulasi efflurage adalah manipulasi dengan menggunaka ibu jari untuk menggosok daerah tubuh yang mengalami kekakuan otot yang bertujuan untuk melemaskan otot dan memperlancar peredaran darah. Teknik efflurage ini bermanfaat untuk mengurangi ketegangan otot dan meningkatkan sirkulasi area yag sakit serta mencegah terjadinya hipoksia (Hartati, 2015: 794); 3) Traction (tarikan) adalah tarikan pada sendi supaya ada peregangan sehingga adanya respon otot disekitar sendi yang nantinya akan direposisi (Graha \& Priyonoadi, 2012: 21); 4) Reposition (reposisi) adalah memposisikan sendi seperti semula pada bagian sendi yang terkena cedera (Graha \& Priyonoadi, 2012: 21).

Terapi masase yang digunakan untuk penanganan berupa cedera akibat dari ketegangan otot seperti nyeri tumit dan nyeri otot tibialis yaitu dengan menggabungkan teknik manipulasi friction (gerusan) dan efflurage (gosokan) menggunakan ibu jari untuk mengilangkan ketegangan otot sehingga otot menjadi lemas. Traction (tarikan) dan reposition (reposisi) pada teknik ini bertujuan untuk mengembalikan sendi ankle dan tumit kembali pada posisinya (Graha, 2012: 80).

\section{METODE}

Desain penelitian ini menggunakan pre-experimental design dengan desain One-Group Pretest-Postest Design. Subjek penelitian ini adalah pemain Futsal SMA Negeri 1 Ciamis yang mengalami cedera nyeri tumit dan nyeri otot tibialis. Penentuan diagnosa pada cedera tersebut dengan menggunakan angket skala numerik. Kelompok dalam penelitian ini diberikan tes awal yaitu dengan diukur derajat nyeri dengan memberikan angket skala numerik. Selesei melakukan tes awal (pretest) kemudian kelompok diberikan perlakukan terapi masase. Setelah selesei diberikan perlakuan tersebut kemudian diukur kembali derajat nyeri dengan memberikan angket skala numerik (posttest). Untuk mengetahui tingkat efektifitas perlakuan terapi masase maka dibandingkan dengan tes awal dan tes akhir. Definisi operasional variabel penelitian ini yaitu, pemain futsal SMA Negeri 1 Ciamis yang mengalami cedera nyeri tumit dan nyeri otot tibialis diukur derajat nyeri menggunakan angket skala numerik sebelum dan sesudah diberikan perlakuan terapi masase untuk mengetahui derajat nyeri tersebut. 


\section{Teknik Analisis Data}

Data penelitian yang telah diperoleh, selanjutnya akan dianalisis dengan beberapa cara, antara lain: a) Data berskala nominal dan ordinal dianalisis menggunakan deskriptif kuantitatif; b) Data bagi data yang berskala interval dan rasio dianalisis menggunakan uji beda dua kelompok berpasangan baik yang parametrik maupun non-parametrik tergantung normalitas sebaran data

\section{HASIL DAN PEMBAHASAN}

\section{Hasil}

Lokasi yang digunakan dalam melaksanakan penelitian di SMA Negeri 1 Ciamis. Penelitian ini digunakan untuk mengetahui efektifitas masase terapi cedera olahraga terhadap nyeri tumit dan nyeri otot tibialis pada atlet futsal SMA Negeri 1 Ciamis. Penelitian ini dilakukan pada bulan April-Mei 2019 dan didapatkan responden sebanyak 30 orang diantaranya 15 orang mengalami cedera nyeri tumit dan 15 orang mengalami nyeri otot tibialis. SMA Negeri 1 Ciamis. Tingkat nyeri perlakuan terapi masase pretest pada tumit dengan jumlah sampel sebanyak 15 orang diperoleh nilai minimum sebesar 5.00, nilai maksimum 9.0, nilai rata-rata sebesar 7.26, dan standar deviasi sebesar 1.22. Hasil deskripsi statistik data tingkat nyeri setelah perlakuan terapi masase/posttest pada sampel yang berjumlah 15 orang diperoleh nilai minimum sebesar 1.00 , nilai maksimum 4.00, nilai rata-rata sebesar 2.46 , dan standar deviasi .91.

Tingkat nyeri perlakuan masase terapi cedera olahraga pretest pada otot tibialis dengan jumlah sampel sebanyak 15 orang diperoleh nilai minimum sebesar 6.00, nilai maksimum 9.00, nilai rata-rata sebesar 7.46 dan standar deviasi 1.06. Hasil data tingkat nyeri setelah perlakuan masase terapi cedera olahraga/posttest pada otot tibialis dengan jumlah sampel sebanyak 15 orang diperoleh nilai minimum 1.00 , nilai maksimum sebesar 4.00 , nilai rata-rata 2.26 , dan standar deviasi 1.03. Dapat dilihat juga dari hasil data perlakuan masase terapi cedera olahraga pada tumit dan otot tibialis menghasilkan penurunan nilai rata-rata dari pretestke posttest yang artinya ada penurunan tingkat nyeri setelah diberikan perlakuan terapi masase.

\section{Efektifitas Masase Terapi Cedera Olahraga Terhadap Nyeri Tumit}

Berdasarkan hasil uji hipotesis diatas, diketahui bahwa nilai rata-rata sebesar 4.80 dengan peningkatan terendah sebesar 4.23 dan peningkatan tertinggi sebesar 5.36 pada $95 \%$ rentang kepercayaan. Nilai sig. sebesar 0.00 (sig. < 0.05), sehingga H0 ditolak dan H1 diterima. Berdasarkan pengolahan uji hipotesis tersebut dapat disimpulkan bahwa terdapat efektifitas yang signifikan masase terapi cedera olahraga terhadap nyeri tumit.

\section{Efektifitas Masase Cedera Olahraga Terhadap Nyeri Otot Tibialis}

Berdasarkan hasil uji hipotesis diatas, diketahui bahwa nilai rata-rata sebesar 5.20 dengan peningkatan terendah sebesar 4.49 dan peningkatan tertinggi sebesar 5.90 pada $95 \%$ rentang kepercayaan. Nilai sig. sebesar 0.00 (sig. < 0.05), sehingga H0 ditolak dan H1 diterima. Berdasarkan pengolahan uji hipotesis tersebut dapat disimpulkan bahwa terdapat efektifitas yang signifikan masase terapi cedera olahraga terhadap nyeri otot tibialis.

\section{Pembahasan}

Berdasarkan hasil analisis data penelitian perlakuan masase terapi cedera olahraga yaitu masase frirage didapatkan hasil analisis uji-t menunjukan bahwa nilai rata-rata yaitu 4.80 dengan nilai terendah 4.23 dan nilai tertinggi 5.36 yang berarti adanya efektifitas masase frirage terhadap penurunan rasa nyeri pada tumit. Secara fisiologis, masase terbukti dapat menurunkan denyut jantung, meningkatkan tekanan darah, meningkatkan sirkulasi darah dan limfe, 
mengurangi ketegangan otot, dan meningkatkan ruang gerak sendi serta mengurangi rasa nyeri (Arofah, 2010:116).

Pemberian treatment masase frirage pada atlet futsal dapat mengurangi rasa nyeri pada tumit karena manipulasi efflurage dan friction dalam masase frirage akan membantu proses untuk menghancurkan myoglosis yaitu timbunan dari sisa-sisa pembakaran pada otot yang menyebabkan pengerasan serabut otot sehingga mengakibatkan timbulnya rasa nyeri (Yulianti, 2015: 22). Rasa nyeri yang timbul akan berkurang dengan melakukan tarikan (traction) pada sendi yang bertujuan untuk meregangkan otot sehingga adanya respon pada otot disekitar sendi yang nantinya akan di reposisi (reposition) untuk mengembalikan sendi yang cedera kembali pada posisi sebelumnya. Perlakuan traksi dan reposisi dapat menurunkan nyeri salah satunya pada ankle dan tumit serta memulihkan ruang gerak sendi yang tadinya terbatas akibat dari cedera yang dialami (Hoffman, 2016: 55).

Stabilitas sendi adalah hasil dari penyelarasan tulang yang tadinya bergeser (subluksasi) atau tidak pada tempatnya. Subluksasi adalah disfungsi pada sendi yang menyebabkan perubahan fisiologis tetapi kontak antara permukaan sendi tetap utuh. Nyeri pada pergelangan kaki diakibatkan karena adanya pergeseran tulang tibia anterior atau posterior tidak pada tempatnya. Mengembalikan posisi sendi menjadi normal sangat penting untuk menurunkan rasa nyeri serta bepotensi mengurangi tekanan kontak abnormal pada tumit (Veljkovic, 2016: 2).

Berdasarkan hasil analisis data penelitian perlakuan masase terapi cedera olahraga yaitu masase frirage didapatkan hasil analisis uji-t menunjukan bahwa nilai rata-rata yaitu 5.20 dengan nilai terendah 4.49 dan nilai tertinggi 5.90 yang berarti adanya efektifitas masase frirage terhadap penurunan rasa nyeri pada otot tibialis.

Masase merupakan salah satu perawatan cedera dengan menggunakan sentuhan untuk merangsang produksi bahan kimia tertentu dalam sistem kekebalan yang mendorong penyembuhan. Masase dapat menghancurkan tumbukan asam laktat yang terakumulasi selama latihan sehingga otot menjadi relaks, meningkatkan sirkulasi darah dan getah bening, meregangkan sendi, serta meredakan rasa nyeri (Kozier, 2018: 284). Pemberian manipuasi masase frirage yaitu gabungan antara gerusan (friction) dan gosokan (efflurage) yang bertujuan untuk memperlancar peredaran darah, merangsang serabut-serabut saraf otot agar relaks, meningkatkan sistem peredaran darah dan melancarkannya, serta mengurangi rasa nyeri dan mempercepat proses regenerasi (Graha, 2012: 21).

Mekanisme pengaruh masase pada penurunan nyeri yaitu Gate Control teori dimana teori ini menjelaskan bahwa rasa nyeri dianggap dapat merangsang serat saraf yang lebih pendek dan kurang terisolasi sehingga sinyal rasa nyeri terhambat untuk sampai ke otak dibandingkan sinyal tekanan yang dibawa oleh serat saraf yang lebih banyak mielin karena mampu mengirimkan rangsangan tekanan lebih cepat dari rangsangan rasa nyeri yang bisa ditransmisikan (Berman, 2015: 1091). Masase mengaktifkan serat berdiameter besar (A $\beta)$, menghambat pesan rasa nyeri yang dibawa oleh serat yang lebih kecil (serat $A \delta$ dan $C$ ) ke otak (Champaneri, 2014: 72). Sinyal tekanan dari masase ditransmisikan lebih cepat agar sinyal rasa nyeri tertutup (Kamali, 2014: 479).

Pemberian masase pada otot tibialis dapat membantu mereleksasikn otot yang tegang akibat dari cedera pada pergelanagan kaki yang mengalami sublukasasi tulang tibia pada sendi ankle dibagian sagital distal tibia. Nyeri biasanya dirasakan disepanjang tepi dalam tibia dimana otot melekat pada tulang (Amin, 2017: 281). Kelelahan otot akibat dari fraktur tulang selama berlari secara terus menerus dipermukaan lapangan yang keras menghasilkan beban tekan pada ektremitas bawah, dan mengakibatkan guncangan dampak yang ditransmisikan melalui musculoskeletal sistem sehingga menimbulkan rasa nyeri (Sheerin, 2018: 3). Aktivitas otot disesuaikan terhadap respon dan karakteristik gaya tumbukan untuk meredam getaran jaringan lunak. Redaman ini dapat terjadi untuk meminimalisir efek merugikan tekanan atau tumbukan 
yang berulang dari kaki. Aktivitas lari yang kompetitif menyebabkan kelelahan otot yang dapat merusak bantalan otot. Kelelahan otot yang diakibatkan karena latihan menyebabkan stres fraktur yang lebih tinggi pada tibia (Giandolini, 2016: 2).

\section{SIMPULAN}

Berdasarkan hasil penelitian yang diperoleh dengan analisis data dan pengujian hipotesa, maka dapat disimpulkan bahwa masase terapi cedera olahraga efektif untuk penurunan rasa nyeri tumit dan otot tibialis pada atlet futsal SMA Negeri 1 Ciamis. Saran yang dapat diberikan adalah pelatih harus mampu menjadi fasilitator bagi atlet untuk dapat meningkatkan kemampuan dan keterampilan secara kompleks sehingga tidak mudah mengalami cedera. Sekolah harus mampu memberikan fasilitas dan mendukung kegiatan latihan agar atlet dapat meningkatkan kemampuan sehingga tidak mudah cedera. Peneliti selanjutnya agar melakukan kontrol terhadap fasktor-faktor yang dapat mempengaruhi latihan dan proses penelitian.

\section{DAFTAR PUSTAKA}

Amin, I., Moroz, A. (2017). Medial Tibial Stress Syindrome (Shin Spints).

Anggoro, A.W., (2014). Penatalaksanaan Fisioterapi Pada Kasus Myalgia (Tibialis Anterior) Sinistra di RST. Dr. Soedjono Mgelang. Naskah Publikasi Universitas Muhamadiyah Surakarta. 1-10

Akoso, B.T \& Galuh H.E. (2005). Natural Healing Series-Natural Holistic Therapies for Common Ailments-Overcoming Digestive Problems. USA: Trident Reference Publishing Arofah, N.I. (2010). Dasar-Dasar Fisioterapi pada Cedera Olahraga. Yogyakarta : FIK UNY Astur, D.C., Zannata, F., Arliani, G.G., Moraes, E.R., et.all. (2016). Stress Fractures: Definition, Diagnosis and Treatment. Rev Bras Ortop, 51 (1), 3-10 Health Information Factsheet. (June 2012). Summit Medical Group, 1-6.

Berman, A., Snyder, S., Frandsen, G. (2015). Kozier and Erb's Fundamentals Of Nursing.

Champaneri, Viral Ishvarlal., Kathrotia, Rajesh., Harsoda, Jaman Mohan., et al. (2014). NonPharmacological Interventions in Algiatry. International Journal of Current Pharmaceutical Review and Research, 06 (08), Page 71-7.

Fondy. T. (2016). Sport Massage Panduan Praktis Merawat dan Mereposisi Cedera Tubuh. PT Gramedia Pustaka Utama. Anggota IKAPI, Jakarta, 2016.

Furlan, A. D., Brosseau, L., Imamura, M., \& Irvin, E. (2004). Massage for lowback pain. Cochrane Database of Systematic Reviews, 2.

Giandolini, M., Gimenez, P., Temesi, J., et.all. (2016). Effect of the Ftigue Induced by a 110KM Ultramathon on Tibial Impact Acceleration and Lower Leg Kinetics. PLoS ONE 11(3), March 31, 2016. 1-18.

Goff, J.D., DO, Crawford, R. (2011). Diagnosis and Treatment of Plantar Fasciitis. American Family Physician, 84 (6), 677-682.

Graha, A.S. (2013). Masase Terapi Cedera Olahraga Metode Ali Satia Graha (Therapy Massage Sport Injury). HAKI Kemenkumham.

Graha, A.S \& Priyonoadi, B. (2012). Terapi Masase Frirage Penatalaksanaan Cedera Pada Anggota Gerak Tubuh Bagian Bawah. Fakultas Ilmu Keolahragaan Universitas Negeri Yogyakarta, 1-109

Hartati, Walin, Widayanti, E.D., (2015). Pengaruh Teknik Relaksasi Front Efflurage Terhadap Nyeri Dismenore. Jurnal Riset Kesehatan, 4, 793-797

Harun \& Fatimah. (2013). Developing Adobe Flash CS 6 Media of Independent Rehabilitation Theraphy Program for Ankle Injuries. Universitas Negeri Yogyakarta, 8 (1), 35-43 Health Information Factsheet. (June 2012). Summit Medical Group, 1-6 
Hoffman, S.L., Hoffman, A.S. (2016). Restrain, Reposition, Traction, and Exercise Device and Methode. United State Patent, Aug. 022016.

Kamali, Fahimeh., Panahib, Fatemeh., Ebrahimic, Samaneh., et al. (2014). Comparison between Massage and Routine Physical Therapy in Women with Sub Acute and Chronic Nonspecific Low Back Pain. Journal of Back and Musculoskeletal Rehabilitation, 27 (4), 475-480.

Kozier, Barbara., Erb, Glenora., Berman, Audrey., et al. (2018). Fundamentals of Canadian Nursing: Concepts, Process, and Practice (4thed.). Ontario: Pearson Canada Inc.

McCall., A., Carling, C., Davison, M., et.al. (2015). Injury risk factors, screening tests and preventative strategies: a systematic review of the evidence that underpins the perceptions and practices of 44 football (soccer) teams from various premier leagues). BJSM. (1).

Setiawan, A. (2011). Faktor Timbulnya Cedera Olahraga. Jurnal Media Ilmu Keolahragaan Indonesia,94-98.

Sheerin, R.K., Reid, D., Besier, T.F. (2018). The Measurement of Tibial in Runners. A review of the Factors That Can Affect Tibial Acceleration During Running and Evidence Based Guidelines For its Use. Journal Gait \& Posture. 1-34

Veljkovic, A., Norton, A., Salat, P., et.all. (2016). Sagital Distal Articular Angle and the Relationship to Talar Subluxation in Total Ankle Arthroplasty. American Orthopaedic Foot\&Ankle Society. 1-9

Wahyu. B, Riyadi. S, Kushartanti. W, dkk. (2010). Masase Terapi Cedera Olahraga. Yuma Pustaka. Kadipiro Surakarta. 2010.

Wolfe, M.W, Clinic, Salem, Virginia. (2001). Management Of Ankle Sprains. American Family Phisician. Vol. 63, No. 1 hlm. 93.

Yulianti, E.P. (2015). Analisis Asuhan Keperawatan Kesehatan Perkotaan Menggunakan Intervensi Swedish Massage Pada Kadar Glukosa Harian Pasien Dengan Diabetes Mellitus Tipe 2 di Ruang Melati Atas RSUP Persahabatan. Karya Ilmiah Akhir Ners UI, $1-80$.

Zen, S. (2017). The Japanese way of Acupunture without Needles. International journal of Complementary \& Alternative Medicine. Volume 6, no. 3. 2017 